\title{
Earthquake Hazard Zoning and Land Use Planning For Urban Areas- A Case Study Chennai City, India
}

\author{
Ganapathy GP* \\ VIT University, India
}

*Corresponding author: Ganapathy GP, Professor \& Director, Centre for Disaster Mitigation and Management, VIT University, Vellore 632014, India

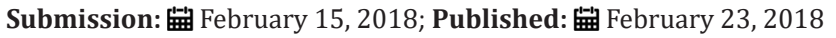

Keywords: Earthquake; Hazard zoning; Land use planning; Urban area; India

Opinion

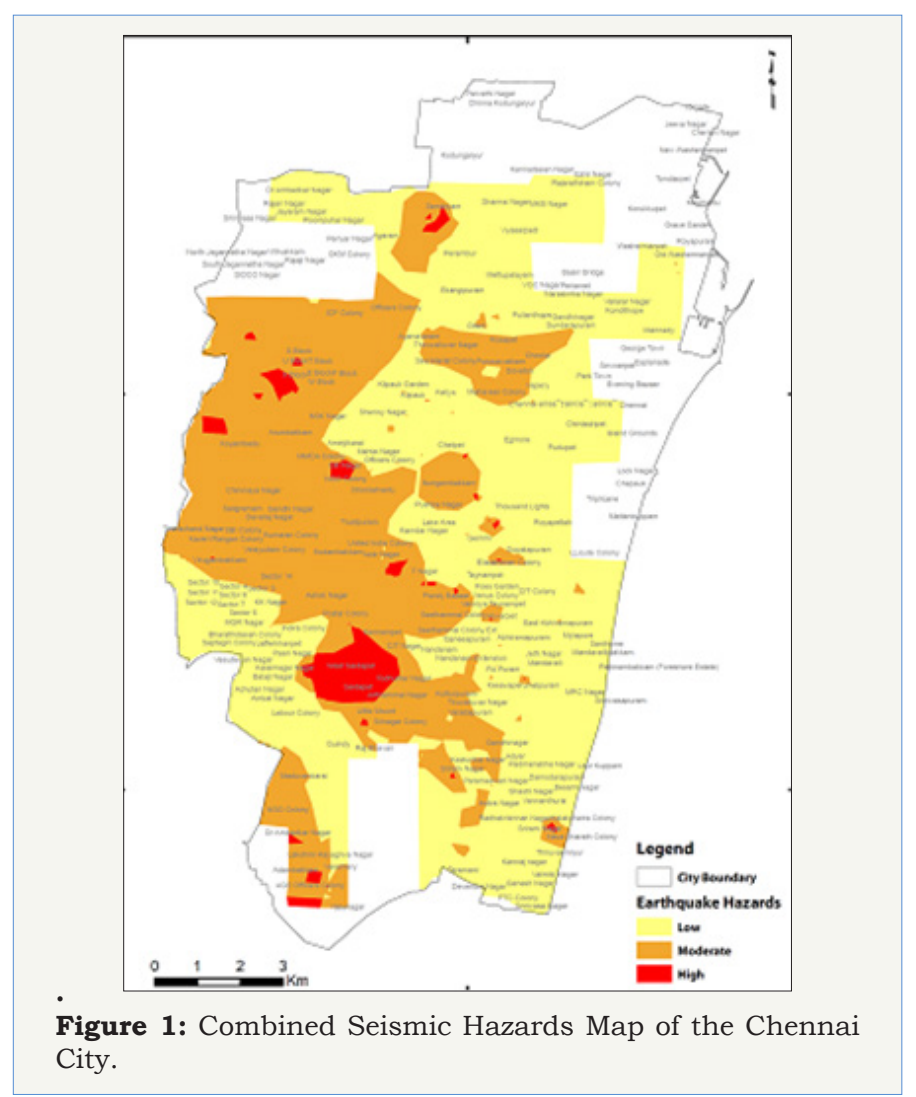

The destruction and damage caused by an earthquake is a consequence of an interaction between the physical event and the built environment. So, to estimate potential losses, one should understand the seismic risk of the area and the information on the population of that area, land use, and building structures. Hazard zoning in earthquake prone areas will be the greater important for land use regulation and planning new developmental activities. Earthquake hazards such as seismic ground shaking and soil liquefaction are the most dangerous during an earthquake. It is very much important to understand these hazards and its consequences in urban centers particularly in the capital cities of the any state, which may end up in severe socio economic damage. Chennai city, which is head quarters of Tamil Nadu state in India is an urbanized area, it's categorized as fourth densely populated city in India. A study has been carried out to understand the seismic hazards of the city using remote sensing and GIS. The seismic hazards viz., seismic ground shaking in terms of seismic micro zonation, liquefaction susceptibility were assessed and integrated in Geographical Information System. For preparation of earthquake micro hazard zonation map the data on geology, faults, seismicity and geotechnical data were used. Geotechnical data were collected and the parameters viz, grain size, effective stress, water table, soil layers, depth were studies and the SPT ' $\mathrm{N}$ ' value to prepare the liquefaction susceptibility map for the city. These maps were integrated in a GIS platform using raster calculation and a combined seismic hazards map was prepared. The areas were divided in the three categories viz., Low, Moderate and High Seismic Hazards (Figure 1).

The hazard mapping will helpful in the demarcation and locating the damaged and destroyed community in case of an earthquake and will be useful to develop appropriate mitigation, preparedness and quick response plans for the these urban areas. Land use planning techniques are most appropriate for generally

the undeveloped land. Another common approach is earthquake loss mitigation to imply building codes and practices/ standards for new and existing construction. This can be done in a general way, being applied to all existing and new development, regardless of its location. The adaptation of land use regulations and the implementing the preparedness plan will increase the capacity of the local officials to quickly respond for the emergency situation. Further the planning techniques viz., 
A. Zoning (special seismic study zone, Hazard overlay zone with performance standard, open space conservation zone).

B. Sub division Standards (Performance Standards for sensitive land, planned unit development, Development Standards).

C. Sensitive Area Ordinances.

D. Building Codes.

E. Hazardous building abutment ordinances.

(c) (i) Creative Commons Attribution 4.0

nternational License

For possible submissions Click Here
F. Special use and critical facility permits

G. Environmental Impact Assessment.

H. Tax Credits.

I. Infrastructure location design standards should be studies and implemented and incorporated in the developmental activities.

The study will be used as first hand information for decision making and earthquake disaster preparedness.

\section{Your subsequent submission with Crimson Publishers} will attain the below benefits

- High-level peer review and editorial services

- Freely accessible online immediately upon publication

- Authors retain the copyright to their work

- Licensing it under a Creative Commons license

- Visibility through different online platforms

- Global attainment for your research

- Article availability in different formats (Pdf, E-pub, Full Text)

- Endless customer service

- Reasonable Membership services

- Reprints availability upon request

- One step article tracking system 